\title{
The European Geopolitical Space and the Long Path to Brexit (The Government and Opposition/ Leonard Schapiro Lecture 2020)
}

\author{
Helen Thompson* \\ Department of Politics and International Studies, University of Cambridge, Cambridge, UK \\ ${ }^{\star}$ Corresponding author. Email: het20@cam.ac.uk
}

(Received 29 April 2020; revised 18 December 2020; accepted 18 December 2020;

first published online 17 February 2021)

\begin{abstract}
Although Brexit had its short-term roots in economic and constitutional legitimation issues, it cannot be explained without considering the European geopolitical space, the EU's contrasting political formations in the security and economic spheres, and the fault lines these produce. Seen from a long-term geopolitical perspective, there have been recurrent problems in Britain's efforts to deal with the EU and its predecessors, and persistent patterns of crisis. The geopolitical environment, especially around NATO and energy security in the Middle East, first rendered non-membership of the EEC a problem, then made entry impossible for a decade, helped make EU membership politically very difficult for British governments to sustain, and then constrained the May governments' Article 50 negotiations. These problems have a singularly British shape, but they cannot be separated from more general fault lines in the European geopolitical space.
\end{abstract}

Keywords: Brexit; the EU; geopolitics; energy; NATO

Britain's departure from the European Union (EU) has been explained as an electoral phenomenon (Clarke et al. 2017; Curtice 2017; Goodwin and Milazzo 2017) in a referendum precipitated by internal Conservative Party problems (Hayton 2018; Lynch 2015) and situated within a general rise in Western democracies of populism (Norris and Inglehart 2019). It has also been explained as a long-term product of the economic and constitutional strains that accompanied Britain's EU membership, especially in regard to Britain's absence from the euro and London's position as the euro's financial centre (Bickerton 2019; Gifford 2016; Rogers 2017; Schelkle 2016; Thompson 2017). But although the foreign policy and security implications of Brexit for both Britain and the EU have been thoroughly analysed (Blagden 2017; Heisbourg 2016; Martill and Sus 2018; Oliver 2017; Wilson 2017), geopolitics has with a few exceptions (Callinicos 2017; Rees 2017) featured less as part of an explanation for Brexit itself.

(C) The Author(s), 2021. Published by Cambridge University Press on behalf of Government and Opposition Limited. This is an Open Access article, distributed under the terms of the Creative Commons Attribution licence (http://creative commons.org/licenses/by/4.0/), which permits unrestricted re-use, distribution, and reproduction in any medium, provided the original work is properly cited. 
By contrast, this article offers a reading of Brexit's causes and the outcome of the Article 50 negotiations on a withdrawal treaty that gives substantial explanatory weight to geopolitics, casting Britain's persistent dilemmas around EU membership in a broader story about a European geopolitical space riddled with fault lines.

The article is divided into five sections. The first lays out an analytical framework for a geopolitical consideration of Britain's EU membership, with some emphasis on energy. The second considers Britain's years outside the European Economic Community (EEC) and the complex path to entry to the European Community (EC) in 1973. The third examines how the problems of EU membership eventually produced British secession. The fourth analyses the Article 50 negotiations. The fifth draws conclusions about Britain's trajectory in the post- World War II European geopolitical space and offers some reflections on the capacity of that space to cause further disruption within the EU.

\section{Geopolitical analysis}

To treat geopolitics as more than a shorthand for 'high' international politics, it must be conceptualized. Here, I take geopolitics as the sphere where states exist in geographical space and have security, economic and domestic political dilemmas that arise from interactions in multiple spheres between states and non-state actors in this space. The continuities of geography ensure that some of these dilemmas do not change rapidly. Indeed, they can only be clearly perceived over the longue durée, relatively independently of any particular national government's specific judgements about how to act in relation to them. From the beginning of the 20th century, energy has been central to geopolitical time. Where oil and gas are physically located, by what means they are transported from where they are produced to where they are consumed, and who decides how much supply is available constrain the external strategies governments can pursue with any efficacy and are part of power relations between states. Once built, gas and oil pipelines become part of the geographical relationship between countries (Gustafson 2020).

Seen in these terms, Europe is a geopolitical space with specific structural features. One of these components is the EU itself, as a multi-state political entity. The EU occupies a very different position in Europe, though, as an economic space rather than as a security or energy space. Through the Single Market, the EU dominates the European economic space, sharply constraining the economic options open to European non-members as well as Turkey. By contrast, where the security space is concerned, the EU is subordinate to NATO. Indeed, NATO makes Europe part of a bigger North Atlantic and eastern Mediterranean geopolitical space that makes the northern Middle East and Caucasus the decisive geographical borders. Crucially, NATO orients Turkey as being inside rather than outside Europe. Seeing as NATO was formed as an anti-Russian alliance and has acted militarily in the Middle East, this security alliance also forces its European members to consider the US in their approach to Europe's neighbouring geopolitical spaces. Moreover, in energy terms, most European states and corporations need long-term relations with the states in these energy-rich spaces since they do not have domestic oil and gas supplies and, after World War II, American presidents did not wish American supply to be exported to Europe except in an emergency. 
How then analytically to treat the EU as a political entity is complicated by this complex geopolitical geography and these differences in its construction in the economic, security and energy spheres. There has been a temptation in EU scholarship to see the EU a genuinely sui generis political entity requiring analytical terms beyond any that can be applied to past multi-state political entities (Glencross 2009; Phelan 2012). But this move encourages unfounded teleological assumptions about union as a historical destiny and empirical and conceptual confusions (O'Leary 2020).

If the EU is susceptible to the terms of conventional political analysis, the question still remains whether it is a confederation - perhaps with consociational features (O'Leary 2020) - a federation (Verdun 2016) - perhaps in a postdemocratic form as executive federalism (Habermas 2012) - or an empire (Zielonka 2006). Obviously, there is a massive and contentious literature on this subject that cannot be considered here. This article starts from the premise that the EU has political features that are confederal, others that are federal, and although it is not an empire it shares some of the predicaments that empires face around unfixed borders. Those parts of the EU that are federal are on the economic side. On the economic side, the federation has two strong elements, namely the Single Market and the eurozone.

Some caveats are, nonetheless, also in order. Britain and Denmark's legal optouts from the euro gave monetary union from the start at least one confederal feature by making initial acceptance of federal authority voluntary. In the case of the Single Market, there is much more enforceable authority than there is any other federal state with a single market, even though the amount of actual integration in the sense of cross-state flows is much less than in the US (Matthijs et al. 2019). By contrast, in security terms, the EU is no more than a confederation and a weak one at that: although the Lisbon Treaty states a commitment to frame a common defence policy for the Union and that member states are obliged to defend each other if attacked, five EU states proclaim themselves to be neutral countries. Energy-wise, the EU is also a confederation, notwithstanding the fact that the Lisbon Treaty made energy a specific sector for primary EU law and the Commission's 2015 Energy Union strategy.

The complex fault lines in the European geopolitical space would appear on the surface to render the EU vulnerable to crisis. In principle, the demands of monetary union, its incomplete relationship to the Single Market, and the EU's security and energy weaknesses could, as Ian Kearns (2018) has argued, pose disintegrative risks for the EU as a whole that could then spill over across the European geopolitical space. But the fact that Brexit at no time looked as if it would lead by contagion to more secessions suggests that the strains arising from within the European geopolitical space are more singular for states than the Union as a whole.

Indeed, for any individual EU state, the structural impact of the European geopolitical space - its borders and relationship to the North Atlantic, Russia, Turkey and the Middle East - is strongly conditioned by their geographical position, their past relationship to the former Soviet and Ottoman imperial presence in Europe, from whom they import oil and gas, their membership or not of NATO, and for NATO members their military importance within the alliance. Of course, these long-term realities do not rule out domestic political contest over geopolitical strategy, but they do create ongoing choices around a set of predicaments that must be 
managed. The constraints, and the choices made in response to them, frequently divide EU members, especially around NATO. Six EU members - including one in the centre of the continent, Austria - are not members of NATO. For the states that were part of the Soviet Union and at least some Warsaw Pact members, NATO is more important than the EU. For Germany, NATO is necessary, but it complicates the country's energy dependency on Russia. Quite singularly, France spent several decades as a military power outside NATO's integrated military command structure, and French presidents would prefer NATO to be more strategically oriented towards North Africa and the Mediterranean and less towards Russia.

Unquestionably, Britain's position in the European geopolitical space has some singularity. It was a founder member of NATO but was late to the EU's predecessors compared with the other large West European states. During the years of its non-membership of the EEC, it was the one North Atlantic power with military responsibility for West European energy security in the Persian Gulf. For a good part of its EC and EU membership, it had a significant domestic oil and gas supply, albeit one that is now quite rapidly diminishing.

However, Britain's geopolitical singularity in the EU is not itself the explanation of why Britain has left the EU. Britain's singularity survived several decades of membership after the 1975 referendum without any risk of secession materializing. Indeed, taking the period that unravelled British membership as 2009, beginning with the eurozone crisis and the Lisbon Treaty's ratification, to the 2016 referendum, then geopolitics in terms of security and energy can readily be left out of the story. As far as events are concerned, economic and constitutional issues and election results were decisive. The crucial junctures before the referendum were the Conservatives becoming the largest party after the 2010 general election, the 2011 European Union Act guaranteeing a referendum on any future transfer of power away from Westminster, David Cameron's veto of an EU fiscal treaty at the December 2011 Brussels summit, the Conservatives' 2015 general election victory, and Cameron's commitment to renegotiate the terms of membership around freedom of movement and protecting the City of London from more regulation by the eurozone members. At none of these moments was geopolitics a prima facie factor in the disruption that occurred. In constitutional terms, parliamentary ratification of the Lisbon Treaty left the Conservatives under David Cameron looking for a treaty with a return of some powers to Westminster on which there could be a retrospective referendum to redress the perceived Lisbon democratic deficit. In policy terms, immigration was the thread connecting the dynamics generated by the eurozone to the constitutional issue because, once migration from southern Europe to Britain began to grow, Cameron was pushed into seeking renegotiation prior to his desired referendum over a matter where existing treaty law would prevail (Thompson 2017).

But beneath the surface, Britain's geopolitical position and the Cameron government's strategic positioning around the long-standing European geopolitical space were consequential. Simply taking the referendum itself, this was on display over Turkey's possible accession to the EU. Some people on the Remain side during and after the referendum were infuriated by the Leave campaign's use of Turkey as an issue, presenting it as exploitative of the contingency of the refugee and migrant crisis (Cameron 2019: 668-669). But Turkey has been a long-term fault line in the European geopolitical space around the NATO-EU division since the 
early Cold War years, and Caspian Sea oil made it an energy one too, by establishing the prospect that non-Russian gas could be brought to Central and South-Eastern European markets in transit via Turkey. In 2009, the EU signed an agreement with Turkey to build the abortive Nabucco pipeline from Turkey to Austria, a development treated by some in the Turkish government as rendering Turkish EU membership an inevitability (Kardas 2011: 38). Coming to power the following year, Cameron's coalition government was strongly committed to Turkish EU membership in a context in which Cameron made reducing other EU states' gas dependency on Russia a strategic priority (House of Commons Foreign Affairs Committee 2012: paras 135, 143). As a result, the fact that Britain's geopolitical positioning on Turkey could intrude on domestic legitimation of the EU was an accident waiting to happen. Moreover, Cameron might be seen to have deliberately tried to keep the Turkey issue out of democratic politics when he excluded future accession treaties from the $2011 \mathrm{EU}$ Act, which otherwise locked in a referendum on any future treaty that transferred more power from Westminster to the EU. In 2012, the House of Commons Foreign Affairs Committee (2012: paras 174-175) cautioned against depoliticizing the Turkey issue. Given that making EU membership a plebiscitary issue in democratic politics broke the constraints party politics set on substantive EU debate, it was highly likely in any referendum that Turkey, which for the government was a geopolitical issue, would feature as a domestic legitimation issue. Indeed, the issue of Turkish membership had already played its part in the 2005 constitutional treaty referendums in France and the Netherlands. Both France and Austria have laws requiring a referendum in the event of Turkish accession. In France, President Jacques Chirac made a commitment to such a referendum before the constitutional treaty referendum took place to try to keep the issue from derailing that vote.

The Turkey issue in the British referendum shows how geopolitical choices shaped by matters that have little directly to do with a state's EU membership can become entangled with it in a context in which democratic legitimation issues around the EU have risen to the fore. This, however, is far from the end of how the fallout of geopolitical divides in and around the European geopolitical space played a causal part in Brexit. The question that hangs over Cameron's failed renegotiations prior to the referendum is why the geopolitical risk for the EU arising from the secession of its most significant military power did not induce the EU to make serious concessions in early 2016. For the period after the referendum, the question arises as to why the British government was unable or unwilling to use the threat of withdrawing from EU security commitments to procure a more palatable withdrawal agreement. These questions, this article argues, can be answered by situating Brexit in the European geopolitical space, as it exists economically, militarily and around energy.

This approach to the geopolitics of Brexit as a geopolitical phenomenon departs from the historiography that places Britain's present EU predicaments in the context of Britain's thousand-year geopolitical relations with continental Europe (Simms 2017). Obviously, there are important continuities, arising from Britain's offshore position. But for all the persistence of old patterns, present British dilemmas exist in a specific geopolitical European space, which crucially includes NATO as the EU's security provider and where most European states are dependent on 
non-European oil and gas. Nor can these dilemmas be separated from the domestic politics of EU membership, or indeed the UK Union, in ways that assume (Simms 2017: 234, 243-244) that geopolitics will always determine outcomes when democratic and geopolitical imperatives clash.

The approach in this article also departs from the political science of Britain's place in the EU's security architecture and diplomacy. There is much insightful scholarship on the diplomacy involved in the security relationship during the late years of EU membership (Whitman 2016), the Article 50 negotiations (Whitman 2017, 2019) and how the EU will continue to constrain Britain's future foreign policy options (Hill 2019). But this kind of analysis generally begins with the EU's institutions and judgements about the EU and Britain's security capabilities; it is less concerned with Europe as a geopolitical space that includes an EU-NATO fault line in a larger geopolitics in which European countries have an external energy dependency. Certainly, some scholars have recognized that Brexit's meaning goes beyond Europe and is part of a bigger geopolitical picture where the American, Russian and Chinese governments have consequential perspectives on Brexit (Oliver 2017) and where, over the past decade, the EU has confronted greater geopolitical uncertainty (Martill and Sus 2019). But, again, energy is absent in a story in which it plays a substantial part.

By contrast, this article takes energy seriously, and it locates the predicaments it creates in a specified time period of geopolitical history in which West European countries made their first moves towards some form of confederation or federation. It makes Britain's structural relationship to the European geopolitical space around energy and the interconnection between energy and military security crucial to junctures of change. Yet it does not make the European geopolitical space determinant of Britain's fate, not least in relation to democratic politics. This is a structural argument with a significant number of contingencies brought about both by the way British governments managed the problem of conflicting geopolitical and domestic imperatives, and by geopolitical events over which neither Britain nor other European states and the EU had much influence. The article's conclusions have implications beyond Brexit. The European geopolitical space is vulnerable to internal and external shocks with the capacity to unsettle the balance of political forces in any European country that sustains any existing combination of EU and NATO commitments as well as long-term energy supplies and the security risks around them.

\section{EEC non-membership}

Britain's dilemmas with a possible West European confederation or federation began in the late 1940s when an American president, and many in the US Congress, wanted recipients of Marshall aid to form a customs union. For Washington, a West European economic federation was a necessary condition of West European security, a problem President Truman did not want to deal with via a military alliance (Steil 2018: 362-363). For the Attlee government, this expectation was doubly problematic. Like the French and Benelux governments, it wanted an American security guarantee, and judged that a West European customs union that included Germany could not be the foundation for a federation to realize 
security when, in its mind, Germany was - like the Soviet Union - a security threat (Warner 1984; Young 1984). In this respect, the fact that the customs union came to nothing and the Truman administration did agree in 1949 to form NATO was a major Franco-British triumph.

But NATO left two unresolved problems that then divided Britain from France, namely French security if and when the coal-rich Saar was returned to West Germany and West Germany's security in regard to the Soviet Union. The European Coal and Steel Community (ECSC) was the eventual French response to the first problem. In choosing the ECSC with its supra-national High Authority, the French government explicitly ruled out other options for dealing with the first problem that would have privileged Franco-British cooperation (Parsons 2003: 49-59). The same year the ECSC was agreed, the Americans quickly brought the second issue to a head by suggesting West Germany join NATO. Since this option was unacceptable to the French, a path now opened to a West European security federation via the European Defence Community (EDC). For Britain, the EDC was initially much more difficult to deal with than either the customs union proposal or the ECSC had been. This time there was sufficient American pressure and financial inducement for the French government, although divided, to move (Duchin 1992). Consequently, the British government could ally neither with France, as over the customs union, nor with the Americans, who had only reluctantly accepted the ECSC. If the EDC had been ratified, Britain would have had to accept a security federation as a neighbour and might have been under persistent American pressure to end its defence sovereignty and join.

This time Britain was saved by the French National Assembly's unwillingness to ratify the treaty. But this was not simply a matter of good fortune, as might be said about the French electorate's unwillingness to ratify the constitutional treaty 61 years later. The British government had leverage over the EDC's fate. Indeed, it was French insistence upon a long-term British troop commitment that effectively derailed the EDC (Deighton 1998: 195). Thereafter, Anthony Eden's government was able to persuade the Americans to retain the security guarantee they had given to the French before the EDC fell, as well as add its own commitment to maintain a standing army on the Rhine via the West European Union. This offer made it possible to persuade the French to accept a rearmed West Germany inside NATO, an outcome which the British government had largely wished for all along (Deighton 1998). Confronted with a choice between a European security federation and strong British participation in a confederal European security structure formalized by turning the Brussels Pact into the West European Union, the French, in the final instance, chose British security participation. If, as Harold Macmillan argued, confederation meant British influence and federation meant a German Europe, then Britain appeared to have rescued its position from the problems Washington first created for it (Deighton 1998: 187).

Although Britain survived its first post-war European trials and the risk of having to form a relationship with an economic or security federation it would not join, there were, by 1955, already indications of some of the deeper trouble to come that would eventually destroy Britain's non-membership of the EEC. The relative success of the ECSC and the failure of the EDC led to new, albeit divisive, talks among the Six (France, West Germany, Italy, Belgium, the Netherlands and 
Luxembourg) for an atomic energy community and a common market that would entail a customs union. If British interests lay in the Six failing to agree in the 1956 intergovernmental conference that led to the Treaty of Rome, it appeared for some time that this outcome was quite probable, especially given how little support in the French political class there was for a common market. Quite how what was a minority position prevailed in France over those who wished to pursue alternative European strategies for France is interesting in itself (Parsons 2003: 90-114). But it was the Suez crisis - the first of what would be several NATO crises over the Middle East that would shape British choices around the EU - that proved a decisive turning point in the EEC materializing (Dietl 2008).

This crisis had two big transformative geopolitical consequences for Europe. First, it pushed France and Britain closer at the expense of the logic of the intergovernmental conference in session, only then to pull France and Britain much further apart, setting a stronger Franco-German alliance in motion. In September 1956, after President Nasser had announced he would nationalize the Suez Canal but before the Franco-British-Israeli action had begun, the French Prime Minister Guy Mollet proposed a Franco-British political union. When the British Prime Minister Anthony Eden was sceptical, Mollet proposed that France join the Commonwealth, accept the Queen as head of state, and that there be the kind of common citizenship arrangements Britain had in place with Ireland (Giauque 2002: 29). Any chance that this proposal could be pursued disappeared when Eisenhower forced British withdrawal from the war by refusing to release oil supplies from the American emergency programme or to give financial support to allow Britain to replace sterling-denominated oil with dollar-denominated oil. On 7 November, the same day that Britain and France succumbed to a United Nations ceasefire, Mollet and West German Chancellor Konrad Adenauer met and resolved what had hitherto been the deep stalemate in the French and German positions over the common market (Parsons 2003: 111). ${ }^{1}$

Second, the Suez crisis graphically demonstrated that NATO provided no answers to West European energy security problems in the Middle East. Seventy per cent of oil sent to Western Europe in 1956 came through the Suez Canal. Adenauer described the British-French military intervention against Egypt as an 'act of European raison d'état' and was appalled that an American president prevented the West European states acting to protect their interests (quoted in Dietl 2008: 261). Once the West European states had directly to confront their energy security interests around the Middle East, the post-war European geopolitical space became reshaped. Some West European states, led by Italy, began to cultivate an energy relationship with the Soviet Union (Cantoni 2017: ch. 4). The French government wanted energy independence and now hoped that a customs union that included oil-rich and French-ruled Algeria would help secure it (Brown 2017). By contrast, the British government thought it could still rely on supply from Iran and Iraq and wished to restore the US relationship. Moreover, despite Suez, the US still very much needed Britain as the only Western power with military bases in the Persian Gulf to protect oil tankers that came through the Strait of Hormuz (Yergin 2009: 498).

The economic side of this new European geopolitical space posed acute problems for Britain because the customs union ensured discrimination against 
British exports. Given the ongoing strength of Britain's Commonwealth trade, British membership would have required a painful economic adjustment (Saunders 2018: 41-43). It would also have meant serious constitutional disruption and posed awkward issues around democratic legitimation. In responding to this setback, the Macmillan government tried to use the security issue to procure a free trade agreement between the British-led European Free Trade Area and the EEC. But Macmillan's threats to withhold on security were useless (Kaiser 1996: 151-152). Quite simply, once Britain had made the commitment to maintain troops in West Germany to Washington as much as Paris, withdrawing them was to all intents and purpose impossible.

The contrasting British and French responses to the Suez crisis also meant the beginning of a long-term conflict between Britain and France about both military and energy security, which deepened after Charles de Gaulle came to power. In part this difference surfaced over nuclear weapons (Hoffmann 1966), but it also arose because the British and French governments never went back to a common position over energy security in the Middle East. For a decade and a half, Washington's need for Britain to deliver security in the Persian Gulf provided a structure to the US-British relationship that was absent between the US and France. This divergence added a sharper geopolitical dimension to what from 1957 were already vexed trade-offs for British governments between economic and constitutional ends.

To make the non-membership predicament worse, de Gaulle's security purposes created a new North Atlantic pressure. Once de Gaulle tried to push for a West European security confederation via the Fouchet Plan - in some sense to replace the EEC - President Kennedy wanted Britain inside the EEC to keep it allied to NATO. Macmillan was inclined to make trade-offs across the European geopolitical space, and he made Britain's first EEC membership application in the hope of obtaining from Kennedy an agreement that the US would provide Britain with Polaris nuclear missiles (Kaiser 1996: 151-173). But doing Washington's bidding to protect NATO from the EEC becoming a security bloc could only invite a French veto and rendered joining the EEC to deal with Britain's European trade problems impossible so long as de Gaulle remained in power.

When membership for economic reasons did become externally viable in the early 1970s, the constitutional problems raised by the primacy of EU law had to be part fudged and part kicked into touch (Thompson 2018). Geopolitically, at this point EC membership did represent a British reorientation towards the European geopolitical space away from the North Atlantic and direct engagement in the Middle East. The end of the French veto on British accession coincided with Britain's withdrawal from the Persian Gulf. In deciding to end military commitments east of Suez, the Wilson government prioritized Britain's military presence in Europe over the Middle East (Saunders 2018: 45) and precipitated a crisis in relations with Washington in making this choice. During the Yom Kippur war and the oil price shock, Edward Heath's government also moved British policy to the French side over Middle Eastern matters, prompting a furious reaction from Henry Kissinger, who suspended American intelligence-sharing with London (Robb 2012). 
Nonetheless, even at the point of accession to the EC, there were clear limits to any alignment of British and French perspectives over both military and energy security around the European geopolitical space. During the 1973-4 energy crisis, the French insisted on independent action, ensuring no collective EC policy emerged. Without one, Heath sided with the Americans over the 1974 Washington Energy Conference (Robb 2012). Meanwhile, de Gaulle's successors remained unwilling to take France back into NATO's joint military command, from which de Gaulle had removed the country in 1966.

Without common security ground between France and Britain, the EC that Britain joined would still be dominated by its capacity for economic federation, realized or aspirational. Whilst British governments had sacrificed Commonwealth trade to participation in a West European customs union, the EC's potential for economic federation was, as Bretton Woods came to an end, also widening on the monetary side. The EC that Britain joined included common monetary arrangements that for Britain would be very awkward. Indeed, in a harbinger of the trouble this issue would eventually bring to membership, the Heath government abandoned sterling's participation in the Snake in the Tunnel, which pegged the EC currencies against each other so that they moved together against the dollar, before accession even took place.

\section{EC and EU membership predicaments}

After British voters kept Britain's EC membership alive in the 1975 referendum, that membership proved somewhat difficult for British governments to manage for the next decade (George 1998). But these tribulations were not politically threatening to Britain's long-term membership. However, this period of relative calm came to an end from the end of the 1980s. This new juncture had two separate causes. First, the EC geared up to become a monetary union. If the monetary union established in the Maastricht Treaty would not quite be a federation, it would have to include one clear federal institution - the European Central Bank (ECB). Second, the EC experienced a geopolitical shock in the end of Soviet rule in Eastern Europe that first opened up a path to the EU becoming a security confederation and then in its medium-term fallout yielded NATO an EU enlargement eastwards.

The first of these developments structurally exposed the weaknesses in the British economic position inside the EC. When the monetary union discussions began in 1988, Britain was outside the Exchange Rate Mechanism (ERM) and there was little prospect that an end to monetary sovereignty could be domestically legitimated (Buller 2000: ch. 6; Thompson 1996: ch. 5). Nonetheless, permanently staying out of the single currency appeared to many within the government a risk. Enough members of Margaret Thatcher's cabinet thought that, since monetary union was likely to happen, keeping options open was the price that had to be paid for retaining British influence within the EC. Thatcher disagreed, and her cabinet colleagues accordingly removed her (Moore 2019: chs 19-21). But John Major's keep-options-open approach was soon wrecked by sterling's exit from the ERM in September 1992. What had been a de facto opt-in to monetary union in the Maastricht Treaty became a clear opt-out. Indeed, this opt-out strategy 
became the template for all awkward treaty changes thereafter (Thompson 2017: 438). In moving to the opt-out strategy, British governments effectively sought to maximize the confederal features of the $\mathrm{EU}$, even as they remained wedded to the clearly federal Single Market.

By contrast, the Cold War's end was in principle an advantage. The EU's turn towards security in the Maastricht Treaty was absolutely confederal and did not require the British government to pursue another opt-out to avoid more federal authority. If the Major government was adamant the new security confederation should remain NATO dependent, it was helped by the fact that the EU's supposed foreign policy 'hour of Europe' in the Balkans turned into disaster requiring NATO intervention. The prospect of new Eastern European members that would value NATO highly also offered the likelihood of future allies to curtail any remaining French ambitions for collective European security autonomy.

Yet for Tony Blair the conjunction of a monetary union that Britain eschewed and a weak security confederation was a liability. He attempted a radical shift in British strategy. For Blair, making the EU a load-bearing security confederation was the only means available to increase British influence inside the EU. An EU that was a deeper security confederation could, he thought, shift the EU's centre of gravity to an area where Britain could exercise leadership (Riddell 2005). This strategy entailed moving closer to France and accepting that the EU should have at least some military independence from NATO. Its result, the bilateral Franco-British San Malo Declaration in 1998, did provide the basis for the EU to acquire some military capability for peacekeeping purposes (Menon 2002) with a stronger security confederation that might even in time have federation potential.

Blair's strategy came apart over events in the Middle East. Blair thought 9/11 made his task easier by re-establishing some North Atlantic unity around terrorism. But Blair damaged his relationship with German Chancellor Gerhard Schröder and French President Jacques Chirac when after 9/11 he invited the Italian and Spanish prime ministers to discuss a European response at a dinner that he had persuaded the German and French leaders to hold just with him (Riddell 2005: 368). The second Iraq war then bankrupted what remained of Blair's ambitions when he could not persuade Schröder and Chirac to support the American military intervention. Moreover, Iraq bitterly divided the EU beyond the British position. Chirac could not contain his fury at those East European states that were about to join the EU siding with Washington over Paris. Without any realistic prospect that, under these geopolitical conditions, the EU would develop as a security federation (Menon 2004), Britain was back to the old problem that being outside monetary union restricted its political influence.

With the intergovernmental conference on the Constitutional Treaty, British politicians also had to contend with the hitherto suppressed constitutional legitimation problems membership had created around treaties against a backdrop of the fallout of the unpopularity of the Iraq war. By 2005, all three then principal British political parties had reached a consensus that there had to be a referendum on the Constitutional Treaty. The manifesto commitment each made could have produced a crisis for British membership, if the Labour government had had to go ahead with a referendum. But this was avoided by the French and Dutch noes to the treaty. The repackaging of the Constitutional Treaty as the Lisbon Treaty restored the problem. 
Gordon Brown responded by ignoring it, in good part because any attempt to re-legitimate membership via any referendum was, as Cameron discovered, very risky.

Once the Conservatives, who had promised a referendum on Lisbon if they were in power before parliamentary ratification occurred, were in office, the eurozone crisis interacted lethally with this constitutional problem since, as argued earlier, it politicized parts of the Single Market in Britain. In wanting an effective emergency brake on freedom of movement as part of his renegotiation, Cameron was forced to take on the Single Market's extremely strong unitary authority. In doing so he condemned himself to asking voters to re-legitimate the status quo of Britain's EU membership after witnessing a demonstration that Britain was part of an economic federation where sovereignty belonged to the EU and not the British Parliament (Thompson 2017: 445-446).

Here we reach the crucial question of why Cameron could not change the calculus confronting the EU-27 such that it did not assess the damage to the Single Market that concessions to Britain would have entailed in relation to the likely geopolitical damage to the EU of British secession on the security side. Procedurally, Cameron made Germany Britain's first and foremost negotiation partner, effectively appealing to the undoubted display of emergency decision-making exhibited by Angela Merkel during the eurozone and refugee and migrant crises and asking her to apply it to the Single Market. Yet German politics is a crucial reason the EU struggles to engage with geopolitical questions around military security and is a weak security confederation. German politicians, including Merkel, tend to assume that because Germany needs NATO to provide military security, the EU-NATO relationship in its existing form must endure regardless of the pressure Germany itself puts on it via Russian energy dependency. Indeed, even after it became clear in late 2019 that Brexit would indeed happen, the German government still seemed to presume that Britain's commitment to European security would continue simply because it is needed. On one occasion, in early 2020 Annegret Kramp-Karrenbauer, Merkel's initial successor as Christian Democrat Party leader, said that on defence and foreign policy 'the UK has to be a privileged third party in our German and EU cooperation' whilst simultaneously warning that a trade agreement would be harder to negotiate because there could be no question of Britain cherry-picking (quoted in Wintour 2020).

Meanwhile, on the French side, where military security around the European geopolitical space very much does matter, the Cameron government was also in a weak position to incite fear. Since 2010, France and Britain had been bound by a bilateral security framework in the Lancaster House treaties. They had acted together independently of the EU and without German participation in Libya. Britain also provided operational support for France's 2013 intervention in Mali that was later extended across the Sahel (Rynning 2017). France, consequently, had an institutional architecture for the security relationship with Britain and the prospect of future bilateral collaboration in the European geopolitical neighbourhood that matters most to France, whether Britain stayed or left the EU. Within the EU security confederation itself, Britain was also still an unreliable ally for France. Although France fully returned to NATO in 2009, François Hollande saw the EU's security confederation in essentially Gaullist terms as an entity that 
needed a stronger federal component and more autonomy from NATO, while Cameron blocked proposals for, among other things, an EU military headquarters. French frustration with Britain was also compounded from 2013 over Syria. The British and French governments had been quite closely allied at the beginning of the Syrian crisis. But Cameron's defeat in the House of Commons in 2013 over the planned airstrikes against the Assad regime and Barack Obama's subsequent decision to abort them led to French isolation. When ISIS then became the problem in Syria, the French started their own independent military action. The French view that NATO simply does not work in the Middle East has origins in this French perception that, as Emmanuel Macron has put it, the American and British retreat from those 2013 air attacks was 'the first stage in the collapse of the western bloc' (quoted in The Economist 2019).

Seen this way, the German government was not movable on the Single Market for Cameron because it does not expect to have to make any concessions in other spheres for geopolitical reasons, and Brexit in principle offered a potential opportunity for France to make the EU's security confederation more federal - as Macron (2017) would later spell out in his Sorbonne lecture - without any real risk of France losing a privileged security relationship with Britain. Unable to raise the geopolitical stakes, Cameron was left pressing vainly against the EU's strongest unitary site of authority.

\section{The Article 50 negotiations}

The Article 50 negotiations were protracted, and in Britain domestically they were politically destructive. Again, their trajectory can in significant part be explained by the way British governments managed them in relation to the European geopolitical space and the broader geopolitical environment of which it is a part. This explanation is far from sufficient; the level of resistance in the British Parliament to Brexit, the assumption inside the EU that this resistance would prevail and the absence of a parliamentary majority for the Conservatives after 2017 cannot be underestimated as sources of British weakness. But the talks did occur in a geopolitical context that, allied to the EU's political formation around security, proved consequential to their outcome.

Again, this context starts with the weakness of the EU as a security confederation. With Britain leaving the EU, moves to which Britain had been opposed could be agreed, including an EU military headquarters, and a framework for some states to integrate further in security policy under Permanent Structured Co-operation (PESCO). In December 2017, the EU's then High Representative for foreign and security policy said: 'All the building blocks of a security and defence union are finally there' (quoted in Sus 2017). One of those building blocks, she could have added, was Brexit. But, of course, the EU actually becoming a loadbearing security federation was an entirely other matter. The EU remained completely constrained in this area by Germany's extremely limited military capability, and by profound internal disagreements about NATO.

The EU's ongoing military reliance on NATO ensured Britain would still be bound into ongoing security cooperation with most EU members whatever happened, and Ireland - which via Northern Ireland, presented the British government 
with its trickiest problem - is a neutral non-NATO member. For the British government to have followed through on the implicit security threat in Theresa May's Article 50 letter (UK Government 2017), there would have to have been sufficient domestic consensus to make leaving the EU about whether Britain could be committed to the European side of NATO too whilst the EU threatened to create a border inside the UK Union, erected tariffs against British exports and made a future trade relationship dependent on accepting EU law. Such a strategy would have meant an overt alliance with Donald Trump. Yet there was nothing remotely like the domestic political consensus to raise the stakes on NATO matters and ally with Trump. Indeed, rather than following through on its security threat, the May government soon decoupled military security issues from Brexit. In the Future Partnership document published in July 2018, it stated that Britain was 'unconditionally committed to maintaining' European security, and could continue to contribute to Common Defence and Security Policy operations (UK Government 2018).

By this point, Macron was well aware that, in reality, any European security ambitions he still had required a close relationship with Britain. What in French terms was previously 'EU strategic autonomy' became 'European strategic autonomy' (Järvenpää et al. 2019). Macron showed no inclination to dispense with the Lancaster House treaties. Rather, he wanted an ongoing security partnership with Britain in some kind of confederal structure beyond NATO. With the European Intervention Initiative (EII) he pushed in 2018 to provide a military capacity for intervention in crises around the EU's borders, he secured it, effectively dispensing with the EU-based PESCO agreed a year earlier (The Economist 2018). That he could succeed was because the May government chose not to use this enduring common security ground with France to try to make the Withdrawal Agreement more palatable to Conservative MPs. Indeed, by agreeing to participate in the EII without then having secured a withdrawal agreement, she went in the opposite direction. Seen this way, no forced choice for the EU between long-term confederal security cooperation with Britain and the Single Market's federal cohesion arose, as there was for the French government in 1954 over the EDC and the costs of isolating Britain in a federal approach.

However, there was a clear change of approach on security and towards the Middle East when Boris Johnson became prime minister. Johnson sought and got changes to the Political Declaration on future military cooperation with new language stating that Britain would retain sovereignty in deciding levels of cooperation. He also immediately made a change on Iran. May had stuck with France and Germany on almost all matters Iranian after Trump ended the Iran nuclear deal. This included trying to put together a European naval response when a British-flagged tanker was seized in the Persian Gulf in July 2019. In his first few days as prime minister, Boris Johnson changed British policy and had the navy join the US-led operation in the Gulf (BBC News 2019; Sanchez 2019). Certainly, afterwards he kept Britain allied to Germany and France in what has proved a vain attempt to preserve the nuclear deal; in January 2020, he also issued a joint statement with Macron and Merkel in response to General Qasem Soleimani's assassination. But Johnson's action over naval operations in the 
Persian Gulf was a demonstration that Britain has in the Middle East the capacity to withdraw cooperation from the EU states and ally with the US.

Johnson's response to the Persian Gulf crisis reveals that the degree to which Britain and other large EU states share energy security interests is very much politically contested, a problem compounded by broader divisions in NATO over energy security. After the Persian Gulf crisis began in May 2019, President Trump expressed frequent frustration that Europe, Japan and China were freeriding on the American navy when, he said, the US no longer needs Middle Eastern oil. In January 2020, the French government announced that a European Maritime Surveillance Mission would operate in the Strait of Hormuz with political support from eight EU states. But the German government was not initially supportive and did not offer ships or planes to the mission (Reuters 2020; Sprenger 2020). Since the German military is weak and Germany now imports relatively little oil from the Middle East, a three-way Franco-German-British split over using naval power in the Gulf is likely to continue.

More broadly, despite the unity displayed over the nuclear deal, there are clear fault lines between Britain and France and Germany over Iran. Britain does much less trade with Iran than the other two. The British government was much more enthusiastic about the new sanctions regime from 2011 that created the conditions for the nuclear deal than the French and Germans. Britain has much closer relations with the Sunni Gulf states, including as a beneficiary of direct foreign investment. The May government banned all wings of Hezbollah, a position that holds in the US but not in the EU or individual EU states except for the Netherlands. For the long term, Britain is also much more tied to oil and gas from the Middle East than France and particularly Germany. As North Sea production dwindles, Britain will become a large importer again, and it does not have an energy relationship with Russia, as Germany, and to a lesser extent France, do, nor could it establish one without a North Atlantic crisis. These differences in part underpin the British naval position in the Persian Gulf. The British navy has now maintained a continuous presence there since 1980. In 2018, after a decision taken four years earlier, Britain opened a naval base in Bahrain, its first permanent military base east of Suez since it retreated from such commitments just before EC accession. Seen this way, the May government's willingness to hug the EU so close on Iran, whilst seeking a relatively close economic relationship, is likely to prove the aberration. Energy security issues in the Middle East will probably strain Britain's future relations with the EU rather than act as an incentive for re-establishing a deep economic relationship within the European geopolitical space. Britain and the EU will not escape the problem of Iran in reconstructing an economic and security relationship any more than Britain and the EEC could the Suez crisis.

\section{Conclusions}

British governments faced persistent difficulties around the EU and its predecessors generated by the European geopolitical space. In part these predicaments arose from the structural fault lines around military and energy security that have run straight through from the late 1940s. For Britain, they have helped make politically sustainable ways of acting in the European geopolitical space extremely difficult. 
During the early Cold War years, Britain's unwillingness to contemplate joining a European security federation effectively stopped the West European states developing even a security confederation. But France's unwillingness to accept that the US could act as a veto power on action oriented towards Western European energy security interests in the Middle East left Britain with costs from staying outside the economically partially federal EEC. Later, Britain's opportunity to lead the EU as a security confederation with France came apart over a US-led, energy-driven war in the Middle East. This left post-2003 British governments to manage all the problems wrought by constitutional legitimation, non-membership of the euro and its consequences for Britain's position inside the Single Market on their own terms without any leverage from the security sphere. Put differently, after the West European Union, British governments could not leverage Britain's security contribution in Europe to stave off unpalatable federal economic outcomes either outside or inside the EU, including Cameron's final attempt at renegotiation. When Theresa May's government appeared to have an opportunity to improve the terms of the Withdrawal Agreement by withholding any commitment to Macron over the EII and support in the Sahel, it prioritized British geopolitical engagement in Europe's neighbouring regions.

Whilst Britain's vulnerabilities to external and internal disruption in the European geopolitical space have taken a particularly brutal course, it would be wrong to conclude that Britain has a unique problem. The present vulnerabilities around the European geopolitical space are obvious. Whilst under Joe Biden Washington's commitment to NATO will be less transactional than under Trump, in an age in which the US can export natural gas to Europe, any American president and Congress will impose significant pressure on Germany to reduce its Russian gas dependency. NATO as a North Atlantic alliance will remain crisis-prone if some adjustment around this fault line does not occur. These divisions within NATO have particular implications for the EU's Eastern European members. For Poland, in particular, an EU where other members destabilize NATO over Russian energy is a serious problem. This risks imposing a choice for Poland at some point in the future between the economic benefits of EU membership and the security imperative to privilege the American relationship; since Poland sits out of the eurozone, a Polish government will not be constrained by euro-denominated debt in resolving it.

Meanwhile, France is now divided from Germany and some other EU members over Turkey. Macron has come to treat Turkey as a strategy and energy-security rival in North Africa and the eastern Mediterranean, and he has effectively offered Greece and Cyprus a bilateral guarantee of naval support in the Aegean against a NATO member. By contrast, the strength of the German corporate relationship with Turkey, the presence of a significant Turkish minority in Germany and the refugee issue have persuaded Merkel that Recep Tayyip Erdoğan must largely be appeased. Although Macron has deployed at times personally confrontational rhetoric towards Turkish President Erdoğan, these differences are structural in regard to French interests in North Africa, the Middle East and the eastern Mediterranean, including around energy security. Where the eurozone is concerned, French presidents must privilege the relationship with Berlin. Moreover, they are no longer in a position to ask for German concessions to protect French economic interests in 
northern Africa, as occurred when French overseas territories were included in the customs union established by the Treaty of Rome.

But whilst the imperative for cooperation with Germany remains acute, the security and energy disagreements with Germany over Turkey can only deepen, especially given Erdoğan's apparent ambitions to create a Turkish sphere of influence in North Africa and expand Turkish naval power. French domestic politics around domestic terrorism and the relationship between Islam and lä̈cité will only harden French choices. Of course, in contrast to the manner in which Britain's monetary outsider position worked to implode British EU membership, France's position inside the euro will constrain the possible outcomes for France. But the fault lines at work around France's position in the European geopolitical space will continue to destabilize that space and shape the EU's future.

Acknowledgements. I am grateful to Laura Cram and Erik Jones for the original invitation to give the Schapiro Lecture and exceptionally helpful feedback put together from referees' reports. My thanks also to Hans Kundani at Chatham House for hosting the lecture and Rosalind Jones for organizing the occasion.

\section{Note}

1 Parsons downplays Suez as an explanation of the shift in French policy but his chronology of early November in fact suggests its significance.

\section{References}

BBC News (2019) Iran Tanker Seizure: Royal Navy Frigate to Escort UK Ships. 25 July. www.bbc.co.uk/ news/uk-49110331.

Bickerton CJ (2019) The Limits of Differentiation: Capitalist Diversity and Labour Mobility as Drivers of Brexit. Comparative European Politics 17(2), 231-245. https://doi.org/10.1057/s41295-019-00160-x.

Blagden D (2017) Britain and the World After Brexit. International Politics 54(1), 1-25. https://doi.org/10. 1057/s41311-017-0015-2.

Brown M (2017) Drawing Algeria into Europe: Shifting French Policy and the Treaty of Rome. Modern and Contemporary France 25(2), 191-208. https://doi.org/10.1080/09639489.2017.1281899.

Buller J (2000) National Statecraft and European Integration: The Conservative Government and the European Union 1979-1997. London: Pinter.

Callinicos A (2017) Britain and Europe on the Geopolitical Roller-Coaster. Competition and Change 21(3), 185-198. https://doi.org/10.1177\%2F1024529417700428.

Cameron D (2019) For the Record. London: HarperCollins.

Cantoni R (2017) Oil Exploration, Diplomacy, and Security in the Early Cold War. Abingdon: Routledge.

Clarke HD, Goodwin M and Whiteley P (2017) Brexit: Why Britain Voted to Leave the European Union. Cambridge: Cambridge University Press.

Curtice J (2017) Why Leave Won the UK's EU Referendum. Journal of Common Market Studies Annual Review 55(S1), 19-37. https://doi.org/10.1111/jcms.12613.

Deighton A (1998) The Last Piece of the Jigsaw: Britain and the Creation of the Western European Union. Contemporary European History 7(2), 181-196. https://doi.org/10.1017/S0960777300004860.

Dietl R (2008) Suez 1956: A European Intervention. Journal of Contemporary History 43(2), 259-278. https://doi.org/10.1177\%2F0022009408089032.

Duchin B (1992) The 'Agonizing Reappraisal': Eisenhower, Dulles and the European Defense Community. Diplomatic History 16(2), 201-221. https://doi.org/10.1111/j.1467-7709.1992.tb00496.x.

The Economist (2018) Emmanuel Macron Leads a New Effort on European Defence. The Economist, 28 June. www.economist.com/europe/2018/06/28/emmanuel-macron-leads-a-new-effort-on-european-defence.

The Economist (2019) Emmanuel Macron in His Own Words. The Economist, 7 November. www.economist. com/europe/2019/11/07/emmanuel-macron-in-his-own-words-english. 
George S (1998) An Awkward Partner: Britain in the European Community, 3rd edn. Oxford: Oxford University Press.

Giauque JG (2002) Grand Designs and Visions of Unity: The Atlantic Powers and the Reorganization of Western Europe, 1955-1963. Chapel Hill: University of North Carolina Press.

Gifford C (2016) The United Kingdom's Eurosceptic Political Economy. British Journal of Politics and International Relations 18(4), 779-794. https://doi.org/10.1177\%2F1369148116652776.

Glencross A (2009) What Makes the EU Viable? European Integration in Light of the Antebellum US Experience. Basingstoke: Palgrave Macmillan.

Goodwin M and Milazzo C (2017) Taking Back Control? Investigating the Role of Immigration in the 2016 Vote for Brexit. British Journal of Politics and International Relations 19(3), 450-464. https://doi.org/10. $1177 \% 2 \mathrm{~F} 1369148117710799$.

Gustafson T (2020) The Bridge: Natural Gas in a Redivided Europe. Cambridge, MA: Harvard University Press.

Habermas J (2012) The Crisis of the European Union: A Response. Cambridge: Polity.

Hayton R (2018) British Conservatism After the Vote for Brexit: The Ideological Legacy of David Cameron. British Journal of Politics and International Relations 20(1), 223-228. https://doi.org/10.1177\% 2F1369148117737278.

Heisbourg F (2016) Brexit and European Security. Survival 58(3), 13-22. https://oi.org/10.1080/00396338. 2016.1186973.

Hill CJ (2019) The Future of British Foreign Policy: Security and Diplomacy in a World after Brexit. Cambridge: Polity.

Hoffmann S (1966) Obstinate or Obsolete? The Fate of the Nation-State and the Case of Western Europe. Daedelus 95(3), 862-915.

House of Commons Foreign Affairs Committee (2012) UK-Turkey Relations and Turkey's Regional Role. Twelfth Report of Session 2010-12, 4 April. HC1567.

Järvenpää P, Major C and Sakkov S (2019) European Strategic Autonomy: Operationalizing a Buzzword. International Centre for Defence and Security, Konrad Adenauer Stiftung. https://icds.ee/wp-content/ uploads/2019/10/ICDS_Report_European_Strategic_Autonomy_Järvenpää_Major_Sakkov_October_ 2019.pdf.

Kaiser W (1996) Using Europe, Abusing the Europeans: Britain and European Integration 1945-63. Basingstoke: Palgrave.

Kardas S (2011) Geo-Strategic Position as Leverage in EU Accession: The Case of Turkish-EU Negotiations on the Nabucco Pipeline. Southeast European and Black Sea Studies 11(1), 35-52. https://doi.org/10.1080/14683857.2011.558721.

Kearns I (2018) Collapse: Europe after the European Union. London: Biteback Publishing.

Lynch P (2015) Conservative Modernisation and European Integration: From Silence to Salience and Schism. British Politics 10(2), 185-203. https://doi.org/10.1057/bp.2015.17.

Macron E (2017) Initiative for Europe. Speech, Sorbonne, Paris, 29 September. http://international.blogs. ouest-france.fr/archive/2017/09/29/macron-sorbonne-verbatim-europe-18583.html.

Martill B and Sus M (2018) Post-Brexit EU/UK Security Co-operation: NATO, CSDP+, or French Connection. British Journal of Politics and International Relations 20(4), 846-863. https://doi.org/10. $1177 \% 2 \mathrm{~F} 1369148118796979$.

Martill B and Sus M (2019) Great Expectations: The Brexit Moment in EU Security and Defence and the Return of the Capabilities-Expectations Gap. Europe in the World: A Law Review 3(1), 1-17. https://doi. org/10.14324/111.444.ewlj.2019.18.

Matthijs M, Parsons C and Toenshoff C (2019) Ever Tighter Union? Brexit, Grexit, and Frustrated Differentiation in the Single Market and Eurozone. Comparative European Politics 17(2), 209-230. https://doi.org/10.1057/s41295-019-00165-6.

Menon A (2002) Playing with Fire: The EU's Defence Policy. Politique Européenne 4(8), 32-45. https:/doi. org/10.3917/POEU.008.0032.

Menon A (2004) From Crisis to Catharsis: ESDP after Iraq. International Affairs 80(4), 631-648. https:// doi.org/10.1111/j.1468-2346.2004.00408.x.

Moore C (2019) Margaret Thatcher: The Authorised Biography. Vol 3: Herself Alone. London: Allen Lane.

Norris P and Inglehart R (2019) Cultural Backlash: Trump, Brexit, and Authoritarian Populism. Cambridge: Cambridge University Press. 
O'Leary B (2020) The Nature of the European Union. In Duina F and Merand F (eds), Research in Political Sociology 27: Europe's Malaise: The Long View. Bingley: Emerald Publishing, pp. 17-44.

Oliver T (2017) Never Mind the Brexit? Britain, Europe, the World and Brexit. International Politics 54(4), 519-532. http://doi.org/10.1057/s41311-017-0043-y.

Parsons C (2003) A Certain Idea of Europe. Ithaca: Cornell University Press.

Phelan W (2012) What is Sui Generis about the European Union? Costly International Co-operation in a Self-Contained Regime. International Studies Review 14(3), 367-385. https://doi.org/10.1111/j.14682486.2012.01136.x.

Rees W (2017) America, Brexit and the Security of Europe. British Journal of Politics and International Relations 19(3), 558-572. https://doi.org/10.1177\%2F1369148117711400.

Reuters (2020) France: More Countries Back European-Led Naval Mission in Hormuz. 20 January. https:// uk.reuters.com/article/uk-mideast-iran-france/france-more-countries-back-european-led-naval-missionin-hormuz-idUKKBN1ZJ1AI (accessed 20 April 2020).

Riddell P (2005) Europe. In Selden A and Kavanagh D (eds), The Blair Effect 2001-2005. Cambridge: Cambridge University Press, pp. 362-383.

Robb T (2012) The Power of Oil: Edward Heath, the 'Year of Europe' and the Special Relationship. Contemporary British History 26(1), 73-96. https://doi.org/10.1080/13619462.2012.656390.

Rogers I (2017) Cameron's Brexit Referendum. Lecture, Hertford College, Oxford, 24 November. www.politico.eu/article/ivan-rogers-david-cameron-speech-transcript-brexit-referendum.

Rynning S (2017) The Divide: France, Germany, and Political NATO. International Affairs 93(2), 267-289. https://doi.org/10.1093/ia/iiw060.

Saunders R (2018) Yes to Europe! The 1975 Referendum and 70s Britain. Cambridge: Cambridge University Press.

Sanchez R (2019) Europeans Stall on Mission to Protect Tankers in Gulf After Raab Calls for Joint Patrols with the US. Daily Telegraph, 27 July.

Schelkle W (2016) Financial Centre and Monetary Outsider: How Precarious is the UK's Position in the EU? Political Quarterly 87(2), 157-165. https://doi.org/10.1111/1467-923X.12243.

Simms B (2017) Britain's Europe: A Thousand Years of Conflict and Co-operation. London: Penguin.

Sprenger S (2020) Germany Wants Another Crack at an EU Mission in the Strait of Hormuz. Defence News, 15 February. www.defensenews.com/smr/munich-security-conference/2020/02/15/germanywants-another-crack-at-a-eu-mission-in-the-strait-of-hormuz.

Steil B (2018) The Marshall Plan: Dawn of the Cold War. New York: Simon \& Schuster.

Sus M (2017) The Future of European Defence Depends on Commitment of Member States. Dahrendorf Forum. www.dahrendorf-forum.eu/the-future-of-european-defence-depends-on-the-commitment-ofmember-states/.

Thompson H (1996) The British Conservative Government and the European Exchange Rate Mechanism. London: Pinter.

Thompson H (2017) Inevitability and Contingency: The Political Economy of Brexit. British Journal of Politics and International Relations 19(3), 434-449. https://doi.org/10.1177\%2F1369148117710431.

Thompson H (2018) Returning to Democracy: The British Left and the Constitutional Temptation of the European Union. In Ekins R and Gee G (eds), Judicial Power and the Left. London: Policy Exchange. http://judicialpowerproject.org.uk/helen-thompson-returning-to-democracy-the-british-left-and-theconstitutional-temptation-of-the-european-union.

UK Government (2017) Prime Minister Theresa May's letter to European Council President Donald Tusk, 29 March. https://assets.publishing.service.gov.uk/government/uploads/system/uploads/attachment_data/file/604079/Prime_Ministers_letter_to_European_Council_President_Donald_Tusk.pdf.

UK Government (2018) The Future Relationship between the United Kingdom and the European Union. July. Cm9593. https://assets.publishing.service.gov.uk/government/uploads/system/uploads/attachment_ data/file/786626/The_Future_Relationship_between_the_United_Kingdom_and_the_European_Union_ 120319.pdf.

Verdun AC (2016) The Federal Features of the EU: Lessons from Canada. Politics and Governance 4(3), 100-110. http://dx.doi.org/10.17645/pag.v4i3.598.

Warner G (1984) The Labour Governments and the Unity of Western Europe, 1945-51. In Ovendale R (ed.), The Foreign Policy of the British Labour Governments, 1945-1951. Leicester: Leicester University Press, pp. 61-82. 
Whitman RG (2016) Brexit or Bremain: What Future for the UK's European Diplomatic Strategy? International Affairs 92(3), 509-529. https://doi.org/10.1111/1468-2346.12607.

Whitman RG (2017) Avoiding a Hard Brexit in Foreign Policy. Survival: Global Politics and Strategy 59(6), 47-54. https://doi.org/10.1080/00396338.2017.1399724.

Whitman RG (2019) The UK's European Diplomatic Strategy for Brexit and Beyond. International Affairs 95(2), 383-404. https://doi.org/10.1093/ia/iiz031.

Wilson GJ (2017) Brexit, Trump and the Special Relationship. British Journal of Politics and International Relations 19(3), 543-557. https://doi.org/10.1177\%2F1369148117713719.

Wintour P (2020) UK Must Get Post-Brexit Defence Privileges Says German Minister. Guardian, 16 January. www.theguardian.com/politics/2020/jan/16/uk-must-get-post-brexit-defence-privileges-says-german-minister.

Yergin D (2009) The Prize: The Epic Quest for Oil, Money and Power. London: Simon \& Schuster.

Young JW (1984) Britain, France, and the Unity of Europe. Leicester: Leicester University Press.

Zielonka J (2006) Europe as Empire: The Nature of the Enlarged European Union. Oxford: Oxford University Press.

Cite this article: Thompson H (2021). The European Geopolitical Space and the Long Path to Brexit (The Government and Opposition/Leonard Schapiro Lecture 2020). Government and Opposition: An International Journal of Comparative Politics 56, 385-404. https://doi.org/10.1017/gov.2021.1 